\title{
Registration of Religious Organizations: \\ Legal Restrictions and Prospects of Development
}

\author{
Anastasia A. Isaeva* \\ Tomsk State University \\ 36 Lenin, Tomsk, 634050, Russia
}

Received 10.03.2015, received in revised form 19.04.2015, accepted 09.06.2015

This article dwells upon some modern legal forms of activities of religious associations and problems of their registration. It is mainly focused on the issues of legal backgrounds in terms of freedom of conscience in Russia, international standards of activities of religious organizations, collective forms of freedom of conscience and religion in the court's decisions. Finally, it discusses the need to amend the existing Russian legislation that does not comply with the principle of secularism, which is stated in the Constitution of 1993.

Keywords: religious association, secular state, state registration, traditional church, confessional policy.

DOI: $10.17516 / 1997-1370-2015-8-8-1580-1590$.

Research area: law.

Relations between church and state have developed through many centuries. The church's role in society has changed, and this is reflected in the basic laws of all countries. The religious question has always been significant for multi-national and multi-confessional Russia. Rules of law traditionally regulate the relationship between state and religious associations. In Russia there are situations where people cannot implement freedom of conscience in its collective form. Existing legal acts set significant limitations on the creation and activity of religious associations. But such restrictions are not imposed on any other type of non-profit organization (e.g. political parties, public associations, and others). This is a limitation of human rights on grounds of faith. At the same time, there are no federal legal norms on missionary teaching of theology and religious culture in educational institutions, chaplains, counteraction of antisocial sects, and state support of socially significant activities of the church. Therefore, activities of religious organizations can be arbitrarily restricted, until they are banned. Additionally, in a situation where there are no federal regulations, regional restrictions may be imposed that do not correspond to the principle of equality of religions (for example, there are certain laws in Voronezh and Belgorod regions, etc.). This

(C) Siberian Federal University. All rights reserved

* Corresponding author E-mail address: tess@mail2000.ru 
practice hinders the progressive development of relations in the sphere of implementation of freedom of conscience. It also leads to violation of human rights, because citizens cannot freely implement freedom of religion collectively by creating a religious association, and some types of their activities may be prohibited at any time. This circumstance does not comply with the country's political course and should be the subject of a legislative reform. The illumination of these defects should become one of the main directions of legislation's reforming.

This article connects legal forms of activities of religious associations with the problem of their registration by decision of the court. It analyzes the legal limitations established for the religious organizations and religious groups and the future perspectives of development of legislation on freedom of religionin Russia. The article consists of four parts. The first describes the legal framework, legal status of religious associations (religious groups and organizations), and discriminatory status of religious groups compared to religious organizations. The second part analyzes international instruments regulating the issue of the status of religious associations and the main principles which should be followed in this field. The third part deals with the jurisprudence of the Russian courts and the Constitutional Court of Russia in terms of assessment of requirements for registration of religious associations. The fourth section sets out the legal positions of the European Court of Human Rights (ECtHR) in order to prevent and eliminate problems in the legal classification of religious groups and the order of their registration.

I shall rely on the comparative analysis in order to suggest amendments to the current Russian legislation to avoid unequal treatment of different types of religious associations, and to exclude significant restrictions on freedom of conscience. The paper examines Russian experience from a comparative perspective. It can be of some help for modernizing current regulations and suggesting possible practical recommendations to legislators.

\section{Russian Legal Background: Issues of Implementation of Freedom of Conscience}

According to Article 14 of the Constitution of 1993, Russia is a secular state. Religious associations shall be separated from the State and shall be equal in terms of the law, and no religion may be established as a state or obligatory one. The Constitution of the Russian Federation considers this provision as one of the fundamentals of the constitutional system.

In the Russian Federation there is a large number of legal acts regulating the status of religious associations. Some laws do this indirectly (as they are not adopted to regulate the status of such organisations as their main objective), but regularly separate elements of the legal status. For example, the counter extremism law places restrictions on religious freedom. In addition to the Constitution (Art. 14, 28, 30), the 1997 Federal Law on Freedom of Conscience and Religious Associations (1997 Federal Law) has an important place in the regulation of questions of implementation of freedom of conscience, including its collective forms. And although the mentioned law mainly corresponds to the provisions of the 1993 Constitution and international obligations of Russia, a number of its provisions, in our point of view, are contradictory in their very nature. When it was adopted at the session of the State Duma of the Russian Federation (the lower chamber of Parliament) on 19 September 1997 V. Zorkaltsev, chairman of the Duma committee on affairs of social and religious associations and one of the drafters of the law, spoke as follows before the law was put to a vote: "Nevertheless, 
I will remind you of the essence of this law. It is this: the law will create a barrier on the path to religious expansion in Russia; it will hinder the development of totalitarian sects and restrict the activities of foreign missionaries, while at the same time creating conditions for the activities of our traditional religions and confessions. I say that to those who today feel that our law is unfit and are planning to vote against it. And I want to put this question to you: whose side are you on, dear colleagues?" That is, the law was conceived as discriminatory from the outset. Its disadvantages include the following: First, the formulation of its preamble is incorrect (Ponkin, 2007). All the religious diversity of Russia is presented as a hierarchy of religions with the recognition of the special contribution "of Orthodoxy to the history of Russia and in the formation and development of Russian spirituality and culture" (Lukin, 1999). Such legal regulation entails preferences for this church and a negative attitude towards new religious movements. Second, the legislators, when dividing religious associations into categories depending on their legal status, did not define the scope of rights of both types. Third, there is an absence of legal guarantees and mechanisms of state support for socially significant activities of religious organizations (such as rehabilitation of offenders, prevention of drug and alcohol addiction, care for socially unprotected people, etc.). Fourth, there is an absence of legal basis and mechanisms of government assistance to religious pilgrimage. Fifth, we face inefficiency and even corruption of the existing order of production of the state religious expert examination (Pchelintsev, 2009; Burianov, Mozgovoi, 2004; Terekhov, 2004). The principle on which the 1997 federal law was based allows the court to prohibit the activities of any religious association and introduces what may be called "a quasi-official religion", because the law establishes a preferential status for "traditional" religious organizations and restrictions for new churches and for the activities of foreign missionaries. But the most discussed and controversial issue is its legal classification and the system of registration of religious associations. The 1997 Federal law provides the possibility of creating two types of religious associations: religious groups and religious organizations. Other types of legal organizational forms are not provided in the legislation. Their main difference is that a religious organization is a registered association of Russian citizens, which has a legal personality. But religious groups have no status of legal entity, and therefore, they have fewer rights. For example, religious groups have no right to establish educational institutions, produce, purchase, export, import religious literature and other objects with religious significance, or to establish mass media. However, all of the above are very typical activities for any kind of a religious association. Therefore, the restricted status afforded to religious groups under the 1997 federal law did not allow members of such a group to enjoy effectively their right of freedom of religion, rendering such a right illusory and theoretical rather than practical and effective (Church of Scientology of St Petersburg and Others v. Russia, no. 47191/06, 2 October 2014).

Moreover, the law imposes restrictions for the registration of religious organizations. Over time, their list is constantly expanding. Today, there are more of them.

Highly controversial is the requirement established by Art. 9 of the 1997 Federal law. It states that a religious organization may be comprised of no less than 10 citizens of the Russian Federation associated as a religious group, having a confirmation of its existence in the given territory within no less than 15 years. In other countries there are no such restrictions 
on the registration of religious organizations or in the country establishes compulsory registration of all religious associations (Argentina, Botswana, Vietnam, Cameroon, Mali, Mongolia, Morocco, Benin Republic, the Slovak Republic, Central African Republic, Switzerland, Sweden), or if the registration is not compulsory, but the participants decide to register their association, they can get a legal status without time limits for the organization's existence in the country. They can be either a non-profit organization (Canada, Turkey), or have a special status as a religious organization (Ukraine, Kazakhstan, Belarus). The term of activity in the country may be considered when the state is granting a special preferential status for religious association (for example, in Austria, when granting the status of "religious confessional communities"). Thus, in Russia if a religious group is not associated with any centralized religious organization, or does not have documents to substantiate its existence in the given territory for 15 years, it will not be registered as a legal entity. Therefore, citizens are not always able to implement freedom of conscience in its collective form as guaranteed by the Constitution and international treaties.

Another controversial requirement is an additional legal restriction on religious freedom in Russia that was made in 2013, not only in the possible range of the founders, but also members of religious organizations. According to par. 3 of Art. 9 of the 1997 Federal law of their number are excluded:first, foreign citizens or stateless persons, in respect of which the legislation of the Russian has been decided about the undesirability of stay (residence) in the country; secondly, the persons included in the list in accordance with par. 2 of Art. 6 of the 2001 Federal Law on counteraction to legalization (laundering) of proceeds from crime and financing of terrorism; third, a person in respect of which entered into force a decision of the court found that his actions bearing signs of extremist activity. Such restrictions are presented controversial not only from the point of view of the constitutional provision on freedom of conscience, but also based on the teachings of a number of religions. According to opponents of such novels, the Church calls for the forgiveness of sins and is ready to take to repent. And in this situation, convicted for certain crimes are denied the opportunity to be members of religious organizations. In addition the implementation of such a rule would inevitably lead to a variety of organizational and technical difficulties. From religious organizations require lists of founders, members and participants. Such lists are very difficult to make, given the historically established organizational structure of many confessions in Russia.

The law has not determined the order of their execution; body to which they must be submitted; the person who should check them and other matters. In general, the verification mechanism "for the opportunity to participate in a religious organization" remains unresolved. Their opinion on these novelties in an open letter to D. Medvedev was expressed by the leaders of the Russian Union of Evangelical ChristiansBaptists. They showed their concern that the law will worsen the moral atmosphere in the society, will create a rift between confessions, raise a wave of religious persecution.

\section{International Standards}

\section{and Legal Framework for the Activities of Religious Organizations}

Because of the significance of entity status to the practical functioning of religious and other belief communities, and because of the variety of ways that States may impinge on the rights of such groups in affording them legal entity status, various countries have made commitments related to the right of religious associations on the status of the legal person. After the Madrid 
meeting in 1983, the participating states of the OSCE reported that they undertake to "favorably" consider applications by religious communities of believers practicing or prepared to practice their faith within the constitutional framework of their States, to be granted the status provided for in their respective countries for religious faiths, institutions and organizations." This position was further strengthened in the Vienna Concluding Document (1989), which pointed out that participating states would not only "favorably consider applications," but also grant upon their request to communities of believers, practicing or prepared to practice their faith within the constitutional framework of their states, recognition of the status provided for them in their respective countries. Thus, the particular form of legal entity can vary in different countries, but access to some form of legal entity, which allows the full range of religious activities, must be provided. Not every type of legal entity allows organizations to carry out the full range of religious activities, and especially as a form of religious group. Provisions of federal law that authorize a legal status to certain organizations (existing in the country for at least 15 years), but also prohibit certain types of activities that do not satisfy this criteria. These provisions fail to comply with standards set down by the Art. 9 of the ECHR, which stipulates no restrictions on collective worship. Since such a limited status does not allow for the organization to realize its basic religious functions. Refusal to provide the necessary legal status means to impose restrictions on the right to practice religion is contrary to Art. 9 of the ECHR. This article guarantees the freedom of thought, conscience and religion. Close relations unite this norm is not only with Art. 8, but also with Art. 10 and 11 , since freedom to practice religion or belief includes the need to appeal to freedom of expression or freedom of assembly. But freedom of religion is not absolute and may be limited. It is difficult to agree that the refusal to grant entity status only by reason of that the organization does not 'exist' before it's a "necessary in a democratic society." (Durham, 1999) Respect for the rights of religious organizations requires that States adopt laws regulating the sufficiently adaptable activities of religious organizations. They must consider the interests of the different types of religious organizations that exist in each country. But Russian legislation has not fixed the international standards of realization of freedom of religion fully. Citizens cannot establish religious organizations without any restrictions.

\section{Evaluation of Case Law in Russian Courts}

In cases relating to the implementation of freedom of conscience Russian courts have made several decisions, but in these the requirement of "fifteen years" has not been assessed.

The most important case was considered in the Constitutional Court in 1999. The Constitutional Court of the Russian Federation considered the appeal of the Religious Society of Jehovah's Witnesses in Yaroslavl City and the religious association "Christian Church Worship." The subject of both appeals was the requirement of Art. 27 of the 1997 Federal Law on the need for annual re-registration of a religious organization for 15 years. In this period, they cannot enjoy the rights provided to other religious organizations. The Constitutional Court has not accepted the provisions of the law as unconstitutional and said that it does not apply to religious organizations established before the entry into force of federal law, as well as local religious organizations, within the structure of a centralized religious organization. In its decision, the court made several conclusions.

First, freedom of religion includes the freedom of creation of religious associations and 
their activities, which is based on the principle of legal equality. A federal legislator has the right to settle civil legal status of religious associations, including the conditions for recognition of religious associations as legal entities, the procedure of its establishment and state registration, and more. At the same time, the legislator should take into account the universally-recognized principles and norms of international law. Measures taken by the state on establishment and registration of religious organizations should not distort the essence freedom of religion, freedom of association and their activities. A possible limitation affecting these and other constitutional rights must be justified and proportional constitutionally to significant purposes.

Second, the state may provide some restrictions, in order not to grant legal status of a religious organization automatically, prevent the legalization of sects that violate human rights and law, and prevent missionary activity, including in connection the problem of proselytism, if it is incompatible with respect to freedom of thought, conscience and religion of other people.

Third, the provisions which are analyzed are to be considered in conjunction with other articles of federal law. Thus, to establish and register a local religious organization, which is the part of a centralized religious organization, the confirmation of fifteen years of existence is not required. And if a religious organization was founded before the entry into force of the federal law, then such confirmation is not required as a religious group has ceased to exist, transforming itself into a religious organization, which was registered as a legal entity and, therefore, considered to be established. Since that point it has obtained legal capacity. On such a religious organization does not extend the requirement for annual re-registration until the period of fifteen years. That is, in its decision the court considered the problem formally. The constitutionality of the restrictions imposed by the law for religious freedom in regard to other religious organizations are not directly considered. Such a position of the court caused a negative assessment from politicians and lawyers, who suggested that the court "elegantly retired from the recognition unconstitutional is clearly, discriminatory rules" that the decision is limited, that it does not prevent religious discrimination, although it formally satisfies the specific applicants (Krasikov, 20004; Lukin, 1999). In its decision the Constitutional Court of Russia, instead of considering the content of the provisions of Art. 27 of the Federal law, found ways to resolve individual problems. It determined that the challenged norms should have an entirely different interpretation. They may not apply to religious organizations that have state registration in accordance with the requirements of the former law.

\section{The ECtHR's Assessment of Collective Forms of Freedom of Conscience and Religion}

The procedure and requirements for registration of religious associations challenges not only in Russia but also foreign countries. Many other European countries have experienced (and many still face) serious difficulties in this matter and the ECtHR had to deal with many cases on this topic. For example, in the cases Kokkinakis v. Greece (no. 14307/88, 25 May 1993); OttoPreminger-Institut v. Austria (no. 13470/87, 20 September 1994); Serif v. Greece (no. 38178, 14 March 2000); Hassan and Chaush v. Bulgaria (no. 30985/96, 26 October 2000); Wingrove v. the United Kingdom (no. 45701/99, 13 December 2001); Kalaç v. Turkey (no.20704/92, 01 July 1997); Metropolitan Church of Bessarabia and Others v. Moldova (no. 45701/99, 27 March 2002); APEH Üldözötteinek Szövetsége and Others v. Hungary (no. 32367/96, 05 October 2000); Magyar Keresztény Mennonita Egyház and Others v. 
Hungary (no. 70945/11, 23611/12, 26998/12, 41150/12, 41155/12, 41463/12, 41553/12, 54977/12 and 56581/12, 8 April 2014). and etc. analyzed the problems of establishing the aim and object of guarantees of the freedom of thought, conscience and religion; forms of realization the freedom of religion; the possibility of state intervention and its limits; the right to exercise freedom of religion in the form of an organized structure and the right to register religious association and have legal entity status; the authorities' refusal to register a group directly affects both the group itself and also its presidents, founders or individual members; the autonomy of religious associations; certain powers of legal entity (such as the rights to own or rent property, to maintain bank accounts, to hire employees, and to ensure judicial protection of the community, its members and its assets) are necessary for exercising the right to manifest one's religion.

One of the first cases concerning the rights of religious associations, was claim of the member of the Religionsgemeinschaft der Zeugen Jehovas and Others v. Austria (judgment of 31 July 2008, №. 40825/98). Austria’s experience is very interesting to Russia for several reasons. Austria, according to the Constitution of 1920 (the Bundes-Verfassungsgesetz), is a federal state as Russia. This fact is important for the demarcation of competencies and powers between the federal government and regions, including on issues of legal regulation of religious associations. In both countries in this area only the federal government may adopt rules of law. Also in the legislation of both countries there are certain periods of time ("trial period"), after which religious groups can be registered. For example, in Russia, registration as a religious organization can happen after a union of persons shall have conducted their activities for 15 years as a religious group. And in Austria, according to the 1998 Law on the Status of Religious Confessional Communities, religious group should exist at least 20 years to become a religious society. In addition, this is the first case consideration by the ECtHR against Austria, which discussed issues about the creation and activity of religious associations. The most frequently discussed is the case on the right of citizens to alternative civilian service (Götl v. Austria, no. 49686/99, 12 March 2009; Koppi v. Austria, no. 33001/03, 10 December 2009; Lang v. Austria, no. 28648/03, 19 March 2009, etc.).

In this case, Jehovah's Witnesses had filed an application complaining on two points. First, they had been denied registration and therefore the right to become a legal entity for 20 years (even though they had obtained it when the application was filed). And second, once they were officially registered, they were denied the more consolidated status of religious society with its special privileges because they did not fulfill the 10 year registration requirement under the law. Religious organizations are divided into three legal categories (listed in descending order of status): officially recognized religious societies, religious confessional communities, and associations. Each category of organizations possesses a distinct set of rights, privileges, and responsibilities. ECtHR, unlike of the Russian Constitutional Court, in the case on appeal of the Religious Society of Jehovah's Witnesses in Yaroslavl City and religious association "Christian Church Worship," considered the merits of the case. It concluded that the ability to establish a legal entity in order to act collectively in a field of mutual interest is one of the most important aspects of freedom of association, without which that right would be deprived of any meaning. The court has consistently held the view that a refusal by domestic authorities to grant legal entity status to an association of individuals amounts to an interference with the applicants' exercise of their right to freedom of association. It also finds that the right of association applies to religious 
followers and that religious freedom must also be guaranteed through the autonomy of religious communities. The court noted that since religious communities traditionally exist in the form of organized structures, Art. 9 must be interpreted in the light of Art. 11 of the Convention, which safeguards associative life against unjustified state interference. Indeed, the autonomous existence of religious communities is indispensable for pluralism in a democratic society.

The most significant of ECtHR decisions in freedom of conscience protection cases against Russia was the decision of the case Kimlia and others v. Russia (no. 76836/01 and 32782/03, 1 October 2009). In other cases, decided by the ECtHR and connected with obstacle to the exercise of freedom of conscience (such as, the Moscow Branch of the Salvation Army v. Russia, Church of Scientology Moscow v. Russia, Kuznetsov and Others v. Russia, Barankevich v. Russia, etc.), the violation of the Convention was established in connection with the fact that it violated Russian law.

In the case Kimlia and others v. Russia violation of the Convention was established in the fact of implementation of the provisions of the 1997 federal law "On Freedom of Conscience and Religious Associations." Thus, the claim that in terms of the Convention the Russian legislation can serve as an object of the procedure (for compliance with the Convention), but not as a regulator, now confirmed the practice of the ECtHR. The court found a direct relationship between the right of freedom of religion and the right of freedom of association, thereby recognizing the right to establish religious associations as part of basic human rights and freedoms. And in the end the ECtHR concluded that the interference with the applicants' right of freedom of religion and association was not "necessary in a democratic society" and there has been a violation of Art. 9 of the Convention read in the light of Art. 11. In this case, unlike in the case Religionsgemeinschaft der Zeugen Jehovas and Others v. Austria, religious associations are generally unable to register and have a legal entity in any of the forms. But by law in Austria they can be registered as a religious community.

Moreover, the fact that the limited status of religious groups under the 1997 Federal law do not make them a sufficient volume of rights for important religious functions also expressed the Parliamentary Assembly of the Council of Europe, the OSCE Office for Democratic Institutions and Human Rights.

Five years later, in the case "Church of Scientology of St Petersburg and others $v$. Russia" (no. 47191/06, 2 October 2014) ECtHR confirmed its position that the lengthy waiting period which a religious organization has to endure prior to obtaining legal personality cannot be considered "necessary in a democratic society". In so far as the fifteen-year waiting period under the 1997 Federal law affected only newly emerging religious groups that did not form part of a hierarchical church structure, there was no justification for such differential treatment. A provision such as this was peculiar to Russian law and there were no other member States of the Organization for Security and Co-operation in Europe that required a religious organization to prove such a lengthy existence before registration was permitted.

\section{Conclusion}

Now in Russia there are many problems in the implementation of freedom of religion. In particular, there is a need to allow the registration of religious organizations without excessive restrictions and to ensure the equal legal status of religious organizations of every kind. The experience of foreign countries can be successfully applied to solve these problems. It is important to develop and adopt a new federal 
law that would exclude the shortcomings of existing rules, including the requirement to wait fifteen years for the registration of religious organizations. This act, in our opinion, should be based on the clear and fully developed concept of relationships within the system: people - church state. However, changing the basic principles of regulating the freedom of conscience and the legal status of religious associations should not be spontaneous. It should be a well thought-out and coherent system of measures, based on the constitutional principles of the secular state and the equality of religious associations.

The implementation of freedom of religion does not depend on the status of a legal entity. Individuals and groups should be free to practice their chosen religion. In turn, the right to acquire the status of a legal entity is an essential, if the religious association wants to go through the registration procedure.

Religious associations of any kind must get a status which would provide all the necessary powers to carry out the full range of its activities. In Russia, religious groups cannot enjoy the full range of rights necessary for worship before registering as the organization after 15 years of existence in the country.

The registration process should not be discriminatory. In a multi-religious country public officials must observe strict neutrality and impartiality in their relations with religious communities.

During the implementation of a new state policy, it is necessary to consistently adhere to the principle of the autonomy of religious organizations. There should notbe any interference in their internal activities, as it takes place in Russia now. All religious organizations must have the freedom to organize in accordance with their hierarchical structures (election of spiritual leaders and appointment to the church office), freedom to communicate with the followers of the respective religion, freedom to receive and publish religious literature, freedom of religion spread outside the places of worship, freedom in the use of the media; freedom in the conduct of educational, charitable and social activities, etc.

New policy should be carried out in phases, with the introduction of new regulations and rules, their approbation, identification gaps and their subsequent elimination. At the initial stage, Russia needs to make changes to the existing federal law. In addition, it would be advisable to adopt legal acts regulating social relations in areas not covered this law (e.g., chaplains and missionary activity, etc.). In any case, there should be no conflict between the Constitution, legislation and practice. Otherwise, it would undermine public confidence in the law and authority.

\section{References}

1. Brian, G.J. (2012). Rising Restrictions on Religion: A Global Overview. BYU Law Review, 3 , 835-872.

2. Bur'ianov S.A., Mozgovoi S.A. Problema realizatsii svobody sovesti i tendentsii votnosheniiakh gosudarstva s religioznymi ob"edineniiami v Rossii [The problems of implementation of freedom of conscience and trends in the relationship between the state and religious associations in Russia]. Moscow, Institute for Freedom of Conscience, 2004. 526 p.

3. Reshenie № 16-P ot 23 Noiabria 1999 po delu religioznoi organizatsii Svidetelei Iegovi [Decision № 16-P of 23 November 1999 in the case of Religious Society of Jehovah’s Witnesses in Yaroslavl and Christian Glorification Church]. Collection of Laws of the Russian Federation, 1999, № 51,63 p. 
4. Reshenie № 46-P ot 13 Aprelia 2000 po delu religioznoi organizatsii Nezavisimaia Rossiiskaia Regionalnaia Organizatsia Obschestvo Iisusa [Decision № 46-O of 13 April 2000 in the case of religious association "Independent Russian Region of the Society of Jesus" ]. Collection of Laws of the Russian Federation, 2000. № 19, 2101 p.

5. Reshenie № 7 on 7 Ianvaria 2002 po delu religioznogo ob"edinenia Moskovskii Filial Armii Spasenia [Decision № 7-O of 7 January 2002 in the case of religious association] "The Moscow Branch of The Salvation Army”. Collection of Laws of the Russian Federation, 2002, № 9, 963 p.

6. Isaeva A.A. Obshchestvenno poleznye religioznye organizatsii: osobennosti statusa, zarubezhnyi opyt, perspektivy ispol'zovaniia $v$ Rossii [Public benefit religious organizations: particular status, foreign experience, use prospects in Russia]. Tomsk, 2014. TSU Publishing House, 128 p.

7. Krasikov, A. (2000). The Constitutional Court and the freedom of conscience in Russia. East European Constitutional Review, 1(30), 234-237.

8. Lewis, V. (2013). Religious Freedom, the Good of Religion and the Common Good: The Challenges of Pluralism, Privilege and the Contraceptive Services Mandate. Oxford Journal of Law and Religion, 2 (1), 25-49.

9. Lukin, V.P. (1999). Vivodi upolnomochennogo po pravam cheloveka v Rossiiskoi Federatsii [The conclusion of the Commissioner for Human Rights of the Russian Federation]. Russian newspaper, 77, 4-15.

10. OSCE (2015), Available at: http://www.osce.org/odihr/16698?download=true (accessed 10 February 2015). Durham C.W. Svoboda religii ili ubezhdenii: Zakony, vliiaiushchie na strukturirovanie religioznykh obshchin [Freedom of Religion or Belief: Laws Affecting the Structuring of Religious Communities].

11. OSCE (2015), Available at: http://www.osce.org/mc/40871 (accessed 10 February 2015). Itogovyi dokument Madridskoi vstrechi 1980 goda predstavitelei gosudarstv-uchastnikov Soveshchaniia po bezopasnosti i sotrudnichestvu v Evrope, sozyvaemogo na osnove polozhenii Zakliuchitel'nogo akta, otnosiashchikhsia k dal'neishim shagam posle Soveshchaniia, Madrid, 1983 (Concluding document of the Madrid meeting 1980 of Representatives of the participating States of the Conference on Security and Co-operation in Europe, held on the Basis of the Provisions of the Final Act Relating to the FollowUp to the Conference, Madrid, 1983).

12. PACE (2014), Available at: http://assembly.coe.int/nw/Home-EN.asp (accessed 10 February 2015). Rezolitsiia 1278 (2002) o rossiiskom zakone o religii, priniataia Parlamentskoi Assambleei Soveta Evropy 23 aprelia 2002 goda (Resolution 1278 (2002) on the Russia's law on religion, adopted by the Parliamentary Assembly of the Council of Europe 23 April 2002).

13. Pchelintsev, A.V. (2009). Chto dolzhno soderzhat regilioznoe ekspertnoe issledovanie [What should the state religious expert examination]. Russian Justice, 3. 47-50.

14. Ponkin I.V. Sovremennoe svetskoe gosudarstvo: konstitutsionno-pravovoe issledovanie [Modern secular state: constitutional legal research]. Moscow, Institute of Church-State Relations and Law, 2005. 413 p.

15. Ponkin I.V. Kommentarii $k$ nekotorym stat'iam Federal'nogo zakona "O svobode sovesti $i$ o religioznykh ob"edineniiah" [Commentary to some articles of the Federal Law "On Freedom of Conscience and Religious Associations"]. Moscow, Institute of state-confessional relations and law, 2007. $120 \mathrm{p}$. 
16. Rivers J. The Law of Organized Religions: Between Establishment and Secularism. Oxford, Oxford University Press, 2010. 424 p.

17. Robbers G. Religion-Related Norms in European Union Law. Trier, Institute of the European constitutional law, 2009. $64 \mathrm{p}$.

18. Terekhov O.N. Problemy razvitiia konstitutsionno-pravovogo statusa religioznykh ob"edinenii [Problems of development of constitutional and legal status of religious associations]. Moscow, 2004. $258 \mathrm{p}$.

19. Federalni Zakon 1997 № 125-FZ [The 1997 Federal Law № 125-FZ On Freedom of Conscience and Religious Associations]. Russian newspaper, 190, 5 p.

20. Fedelalni Zakon 2013 № 180-FZ [The 2013 Federal Law № 180-FZ On introducing amendments to Article 9 of the Federal Law "On Freedom of Conscience and Religious Associations"]. Russian newspaper, 145, 7.

\title{
Регистрация религиозных организаций: правовые ограничения и перспективы развития
}

\author{
А.А. Исаева \\ Томский государственный университет \\ Россия, 634050, Томск, пр. Ленина, 36
}

В статье рассмотрены некоторые современные организационно-правовые формы деятельности религиозных объединений и проблемы их государственной регистрации. Статья сосредоточена на вопросах правовых оснований осуществления права на свободу совести в России, международных стандартах деятельности религиозных организаций, отдельных аспектах реализации коллективных форм свободы совести и вероисповедания, нашедших отражение в решениях различных судебных инстанций. Обсуждается необходимость внесения изменений в действующее российское законодательство, которое не соответствует принщипу светского государства, закрепленного в Конституции 1993 года.

Ключевые слова: религиозные объединения, светское государство, государственная регистрачия, конфессиональная политика.

Научная специальность: 12.00.00 - юридические науки. 